\title{
Heaven and the Goodness of God
}

\author{
Jerry L. Walls
}

check for updates

Citation: Walls, Jerry L. 2021. Heaven and the Goodness of God. Religions 12: 316. https://doi.org/ 10.3390/rel12050316

Academic Editor: James Sterba

Received: 22 March 2021

Accepted: 27 April 2021

Published: 29 April 2021

Publisher's Note: MDPI stays neutral with regard to jurisdictional claims in published maps and institutional affiliations.

Copyright: (C) 2021 by the author. Licensee MDPI, Basel, Switzerland. This article is an open access article distributed under the terms and conditions of the Creative Commons Attribution (CC BY) license (https:// creativecommons.org/licenses/by/ $4.0 /)$.
Department of Philosophy, Houston Baptist University, Houston, TX 77074, USA; dantejlw@gmail.com

\begin{abstract}
In this essay, I argue that we should take fully seriously the doctrine of heaven when dealing with the problem of evil in our world. The hope of heaven is integral to Christian theism so it cannot be neglected in any substantive discussion of the problem of evil. Indeed, heaven provides resources to respond to even the worst of evils and to fully redeem them in such a way that the victims of those evils can fully affirm the goodness of their lives. Anyone who achieves heaven will experience a good of such significance and value that the ultimate beauty and goodness of their life could not be questioned. The Christian doctrine of the afterlife also provides resources to make sense of ultimate accountability. The perpetrators of horrendous evil cannot escape and will be called to account for their actions. However, even those who have committed such evil evils can be fully transformed in such a way that they can be fully reconciled with their victims and heartily embraced by them. This shows the doctrine of heaven to be not only profoundly hopeful, but also starkly honest and realistic.
\end{abstract}

Keywords: horrendous evil; incommensurate good; optimal grace; sanctification; forgiveness; Marilyn Adams; William Hasker

James Sterba lays down an interesting challenge in his recent article, "Is a good god logically possible?" Acknowledging that he was formerly not only a theist, but a Christian, he informs us that he would happily give up his atheism if anyone can poke a hole in his argument. This is a great reminder that issues of theodicy, and of philosophy of religion generally, are not mere academic debates, but rather issues of pressing existential concern. What is at stake in this debate is of enormous significance for every single human being. No informed person can rationally be indifferent to the issues that are on the line here. The problem of evil is very much an existential issue for all of us.

I shall respond to Sterba not so much by trying to poke holes in his argument, but rather by showing a way that God can be vindicated as perfectly good, even though he allows the horrific evils of this world. In saying God "allows" horrific evils, I am assuming that creaturely free will is a good thing, although it has been abused, and that such freedom accounts for much of the evil in our world. This does not mean that those who abuse their freedom by committing such evils are justified, or that the evils themselves are justified. But it does mean that God's perfect goodness will be vindicated in the end and he will be seen as justified. I begin by telling a true story of a horrific evil that happened to the sister of one of my former students.

\section{Moral Absurdity or Profoundly Moral Aspiration?}

Sixteen years old Suzy Holliman was home alone one day, missing school because she had the flu. That was the day Ricky Lee Sanderson chose to burglarize the house, seeking money to support his drug habit. Finding Suzy at home, he raped her and then locked her in the trunk of his car, before killing her. As he dug her grave, she scratched on the locked trunk of the car, desperate to escape the horrific fate she no doubt realized awaited her. After digging the grave, Sanderson strangled and stabbed her to death.

Not long afterwards, Sanderson was arrested and then pled guilty to the charges of kidnapping and murder. Two years later, he was sentenced to death for his heartless crime. 
However, that is not the end of the story. He was converted to Christianity after he was imprisoned and became an outspoken witness for his faith in the years leading up to his execution. He was encouraged to make further appeals but refused to do so and requested that he be executed because he claimed to be concerned that further delays would cause unnecessary suffering for the Holliman family. When he eventually went to his death thirteen years after committing murder, he claimed to be at peace and even went so far as to say that he was prepared to face his victim in the life to come. "I think about facing Suzi Holliman when I'm executed. What's that going to be like? I'm ready to do it. I'm going to be with Christ." (Walls 2002, p. 128).

Suzi's father was understandably dubious about Sanderson's claim to conversion. Despite the facts that he is a practicing Christian, Hugh Holliman made no attempt to hide his true thoughts or to masquerade his honest feelings. Rather, he was brutally honest about his own deeply conflicted feelings about the man who had ruthlessly murdered his daughter, and then professed to be a follower of Christ who anticipated meeting his victim in the life to come. "The hopes and dreams he took away from us and the world-I tried but I can't forgive him. You know there is forgiveness there, but I can't see God totally forgiving him for something like that." (Walls 2002, p. 115).

Hugh Holliman's doubts that even God can forgive such a heinous act are reminiscent of one of the most famous passages on the problem of evil in the literature, namely, Ivan Karamazov's rejection of theodicy. Ivan comes to his despairing conclusion after rehearsing a series of horrendous abuses of children including that of a peasant boy who hurt the paw of a powerful general's dog with a rock he had thrown. The general stripped the boy naked and then forced the mother to watch as he set loose his dogs on the child, who was torn to pieces. Speaking for these victims, Ivan announces that he does not wish to see the mother forgive the general on behalf of the child in the final harmony at the end of the world.

She dare not forgive him! Let her forgive him for herself, if she wants to, let her forgive the tormentor her immeasurable maternal suffering; but she has no right to forgive the suffering of her child who was torn to pieces, she dare not forgive the tormentor even if the child were to forgive him! And if that is so, if they dare not forgive, then where is the harmony? Is there in the whole world a being who could and would have the right to forgive? I don't want the harmony; for the love of mankind I don't want it (Dostoyevsky 1992, p. 254).

As Ivan sees things then, his very love for humanity requires him to reject the promise of the life to come and the hope it offers that the evils of this world might be redeemed. Indeed, as he sees things, some evils are so egregious that they can never be forgiven, and this means some relationships are so badly shattered that they can never be healed, even if there is life beyond the grave. Notice, moreover, that Ivan registers his protest precisely on behalf of the victims of horrendous suffering. It is, he claims, his very love for these persons that requires him to reject the hope of heaven, and to resign himself to the hopeless despair of endless moral indignation.

The promise of heaven is a frontal challenge to the despairing resignation of Ivan. One of the most moving, and memorable, descriptions of what will happen when heaven comes to earth, and God makes his home with his children, is that "he will wipe every tear from their eyes. There will be no more death or mourning or crying or pain, for the old order of things has passed away" (Revelation 21:4). As beautiful as this description is, it is no less staggering. Heaven will no doubt be filled with not only persons who have wept many tears, but also with those who have caused those tears. If heaven is real, there will no doubt be many former thugs, racists, rapists, murderers, adulterers, terrorists, and schemers there along with their victims. Is the hope of such a place realistic, or is it pious nonsense? Is heaven a moral absurdity or is it a profoundly moral aspiration?

\section{Who Has the Moral High Ground?}

Let us begin to explore these questions by asking who really has the moral high ground in this dispute. Atheists often assume the moral high ground in the problem of 
evil debate, contending that belief in an all powerful and perfectly good God is a morally insensitive thing to hold in view of the terrible evil in our world. Indeed, this is just the sort of stance Ivan takes in the famous passage cited above. It is precisely his love for mankind that will not allow him to believe in a perfectly powerful and good God and in a heaven that will redeem the tears of little children who have suffered so terribly at the hands of heartless tormentors. His protest against heaven is fueled by moral indignation.

It is worth emphasizing, however, that the perception of such heartless evil that inspires the passionate response of Ivan may well call forth a radically different response, and indeed, a response that is no less sensitive to the horror of terrible evil. Peter van Inwagen no doubt speaks for many when he remarks that he has "never had the least tendency to react to the evils of the world by saying 'How could there be a loving God who allows these things? My immediate emotional reaction has rather been: 'There must be a God who will wipe away every tear; there must be a God who will repay." (van Inwagen 1994, p. 97).

Van Inwagen's response is very much characteristic of what I mean by an existential response to the problem of evil. His response is very much that of one who is personally invested in the issue, not only for himself but for others as well. He does not approach the matter merely as an interesting puzzle to solve. He realizes that his own life as well as that of others depends on whether or not there is a God. He cannot approach the matter with objective indifference given what is at stake.

Of course, this hardly settles the matter of whether there is a God or not. Still, it is worth highlighting the fact that a keen sense of the horror of evil may elicit from some a strong conviction that there must be a God as surely as it elicits from others a passionate conviction that there cannot be a God.

In any case there is a further point to be made here. It is arguable that if one is truly concerned for the suffering of innocent persons as Ivan eloquently claims to be that one should at the very least strenuously hope that there is a God and an afterlife that will set things right rather than reject that hope. Richard Creel urges this hope upon us and presses the limits of how far we should take this.

Why hope that there is a God? Because of compassion for those who have suffered innocently; because of desire that their suffering not have been useless and terminal, i.e., redeemable after death. As long as it is logically possible that evil be defeated, that innocent suffering is not meaningless and final, it seems to me that we have a moral obligation to hope that that possibility is actual. Therefore, we have a moral obligation to hope that there is a God because, if there is a God, then innocent suffering is not meaningless or final (Creel 1986, p. 149).

Again, this is not a dispassionate response. It is motivated by compassion for those who have suffered, and "desire" that their suffering is not the last word on their lives.

By contrast, Ivan's protest "for the love of mankind" has the ironic effect of writing off the terrible suffering of the very people for whom he claims to be concerned. His rejection of the hope of heaven pronounces a sort of finality upon the suffering of the very people he claims to care so much about. The losses they have sustained are permanent and can never be redeemed. The little boy who was torn to pieces spent his final few moments in utter terror. At best, the story of his life will remain as a testament to the absurdity of life. His dying cries will forever remain unanswered by a pitiless universe and we shall never again hear from him. Moreover, there are countless innocent sufferers never acknowledged in history books or classic novels, and their tears too soak the earth but no one will ever know them or personally care about them.

In view of all this, Ivan's claim of the moral high ground is dubious to say the least. Indeed, his atheism has far less concern for innocent sufferers than it may initially seem. Perhaps this better helps us to understand van Inwagen's emotional response to the evils of this world. Perhaps we too can understand Creel's insistence on why we have a moral obligation "for the love of mankind," to hold fast to the hope that God exists and that heaven can redeem even the worst of evils. 
Christians in fact believe that such hope is not only existentially demanded, but also rationally warranted, and that we are not in fact reduced to desperately clinging to the mere logical possibility that God exists. Rather, we have ample warrant to believe not only that God exists, but that his perfect love and goodness will be fully vindicated.

\section{An Incomparable Good}

Marilyn Adams has attempted to show this in response to the problem of horrendous evil by appealing to some central themes in Christian theology. It is important to emphasize here that she is not required to invent some novel ideas to respond to evil, but only to take seriously the resources of classical Christian belief.

In the first place, Adams has developed the idea that an intimate relationship to God is an incommensurate good, and that recognition of this good is an essential resource in a satisfactory theodicy. That is to say, God is a good of such overwhelming value that he is simply incomparable with respect to any finite good, however extraordinary and attractive. Any attempted comparison would utterly fail to compute. Here it is important to recognize that it is simply fundamental to Christian theism that an intimate relationship with God is not only the greatest possible good for created beings, but that it is the one essential thing for deep and lasting happiness and satisfaction.

Given the supreme nature of this good, any person who achieves it will ultimately be perfectly happy regardless of how much or how grievously he suffered in this life. By contrast, any who does not achieve it will end up miserable regardless of how much pleasure or satisfaction he enjoyed in this life. A loving relationship with God is the greatest possible good and the loss of this relationship is the worst possible evil. The radical significance of this and the implications of it can hardly be overstated. Adams spells out the profound implications for the problem of evil.

If a face-to-face vision of God is an incommensurate good for human beings, that will surely guarantee, for any who has it, that the balance of goods over evils will be overwhelmingly favorable. Indeed, strictly speaking, there will be no balance to be struck. And no one who received such benefits would have any claim against God's justice or complaint against his love. God will have bestowed on those who see him 'up close' as great a good as such a finite container can take (Adams 1992, p. 183).

Notice the last line: this represents the greatest possible good for these persons. The happiness envisioned simply could not be surpassed.

It is important to stress that this supreme good is incommensurate not only with other goods, but also with evils. There simply is no way to compare or measure the joy of this supreme good with finite goods or evils. The beauty and goodness of God as experienced "up close" is of such incomparable value that it will utterly swamp any evils we might have experienced. The apostle Paul seems to have had some such thought in mind when he wrote that "the sufferings of this present time are not worth comparing with the glory about to be revealed to us" (Romans 8:18).

There is a second point Adams develops in addition to the fact that an intimate relationship with God is a good of such value that it cannot be compared to any finite goods. God also has the supreme power and creativity that will enable him to fashion of any of our lives something of extraordinary beauty regardless of the harm and damage we have experienced in this life. One of the devastating things about evil is its power to shatter our lives in so many ways. It can crush our spirits as well as mangle and distort our bodies. It can shred our psyches and mutilate our emotions.

This is a most distressing reality for the likes of finite beings like ourselves. The hard truth is that such evil is altogether beyond our capacities to repair. As Adams puts it, our "meaning making capacities" are completely overwhelmed by such horrendous evil, and we are forced to consider the unhappy conclusion that "lives marred by horrors can never again be unified and integrated into wholes with positive meaning." (Adams 1999, p. 148). 
This is perhaps even more of a challenge for those who have experienced long term suffering, which can be more painful and difficult to heal in significant ways than even intense short term suffering. In such cases, there may be far more damaged pieces, and perhaps more extensively damaged ones, to unify and integrate into a beautiful whole. Indeed, to finite creatures, again, it may seem inconceivable and utterly impossible.

Consider again the little boy who was torn to pieces when the heartless general set loose his dogs on him. It is not only his body that was torn to pieces, his very life was also ripped apart. We may understandably doubt that his body, let alone his life, could ever be put back together again. However, here is where belief in God makes an enormous difference. We may rationally hope that where human imagination and resources utterly fail, God's infinite capacities do not. Not only can God put this little boy's life back together, he can make it of it something extraordinarily beautiful.

So let us recall Ivan's protest against heaven, one that he registers "for the love of mankind." Is it really objectionable to think God should put this boy's life back together since he allowed it to be shattered in the first place? Is there something objectionable in believing that God should shower upon him the sort of love that he never knew in this life since God allowed the general to commit such atrocities against him in this life? Is it really better that his tragic life should stand forever as a monument to heartless cruelty than that God should pick up the pieces of his broken life and put them back together as something of stunning beauty and positive meaning?

I do not see how anyone who cared for this young boy could maintain this protest or presume to hold the high moral ground that Ivan seems to claim. Quite to the contrary, it is not only better, but immeasurably better to hope that heaven is real and that God has the resources to overwhelmingly defeat whatever evils have been suffered in this life.

Indeed, this case brings into sharp relief the ultimate difference between Christian theism and atheism with respect to the problem of evil. We can opt for despair or we can believe, or at least hope, that there is a God with infinite power and creative resources, as the Christian tradition affirms. If there is such a God, he is ultimately responsible as its creator to fix the evils of our world, whether those evils are excruciating short term tragedies, or cases of enormously complicated long term suffering. While God's creative redemption does not justify evil, God himself is justified if he redeems evil and restores creation to a condition more glorious than we can imagine. In any case, this is simply the logic of Christian theism, and we should not fail to bring all of its resources to the table when we deal with the problem of evil.

\section{Not Just Forgiven, Utterly Transformed}

Now here it may be objected that Ivan's complaint is as much about the perpetrators of treacherous crimes as it is their victims. Even if there is some way God can redeem the lives of those who have suffered greatly, the perpetrators of these horrific crimes should not be forgiven, ever. So it would be wrong for the mother whose son was torn to pieces to forgive the general and it would likewise be wrong for Suzy Holliman's father to forgive Ricky Lee Sanderson. If this is so, the moral objection to heaven remains intact.

Raising these questions does point up the radical claims of the Christian gospel. Recall Ivan's pointed question: "Is there in the whole world a being who could and would have a right to forgive?" The Christian answer to this question, of course, is that there is indeed such a person, namely Jesus Christ. He has the right to forgive first and foremost because he is God, the one against whom all sins are ultimately committed. Moreover, he is the one person who is sinless, who is fully perfect, and who offered his life as atonement so that sinners could be forgiven.

So this is the hopeful, yet disconcerting good news of the gospel. Not only is it the case that all other persons need to be forgiven, but all of them can be, even the worst among us. Moreover, this stunning claim has a large practical implication. Since all of us need forgiveness, and Christ offers forgiveness to all, none of us are in position to withhold 
forgiveness from others. "Just as the Lord has forgiven you, so you also must forgive" (Colossians 3:13 NRSV).

However, there is another important point we need to make here pertaining to forgiveness, and that point is that forgiveness alone is not sufficient to get to heaven. Forgiveness is only the beginning of a saving relationship with God. It is also crucial that we actually come to achieve "the holiness without which no one will see the Lord" (Hebrews 12:14 NRSV). This is crucial to help us understand why it is not absurd to think Suzy Holliman's father could heartily embrace Ricky Lee Sanderson in the life to come.

Here is why. Everyone in heaven will not only be forgiven, but utterly transformed into the image of Christ. I am in no position to judge the sincerity of Ricky Lee Sanderson's conversion and his anticipation of meeting Suzy in the life to come. However, if he truly placed his faith in Christ, if he honestly faced the horror of his sin and sincerely repented of it, and underwent the sanctifying process that actually makes us like Christ, then there is an important sense in which he will not be the same man who heartlessly murdered Suzy Holliman. He will be the same man numerically of course, but his character, his heart, his feelings etc. will be radically transformed. He will have come to see the horrific crime he committed through the eyes of Christ, and will not only see with full clarity the pain he caused, but he will also hate his sin as God does, and profoundly regret that he ever committed it. Indeed, to embrace Sanderson would be like embracing Christ himself, for every redeemed and transformed person there will be in this sense nothing less than a "little Christ," as C. S. Lewis put it (Lewis 2001, p. 199).

It is important to emphasize here that Ivan's protest against heaven loses its moral force when we grasp that our final salvation is not merely a matter of forgiveness, but also a matter of thorough transformation. Heaven without the purgatorial fires of radical moral transformation may be vulnerable to Ivan's protest, but heaven preceded by total transformation holds the moral high ground against Ivan's protest. ${ }^{1}$

\section{Embracing the Joy}

Our discussion thus far has shown that Christians have some distinctively powerful resources to deal hopefully with tragedies of the past. However, even if we have reason to hope that such tragedies can be redeemed, it is natural to regret that they ever occurred in the first place. Natural though this feeling may be, it raises serious difficulties as William Hasker has shown in a fascinating discussion of the implications of such regret. So let us turn now to consider some of these issues.

Hasker's analysis of these issues involves some rather precise definitions of what it means to regret something on the whole, on the one hand, and to be glad on the whole that something is the case, on the other. As he notes, the notion of being "glad on the whole" is a rather strong attitude of preference. It requires that one takes all relevant factors into account and still prefers the state of affairs in question to be the case. Being glad on the whole is thus distinct from what he calls being "circumstantially glad," which is a weaker form of preference.

Here is an example from Hasker. Suppose I am glad that Indiana won the NCAA Championship in basketball, defeating North Carolina in the final game of the tournament. Though I am very pleased they won, I might nevertheless prefer that there was no tournament at all because I regret the existence of the NCAA with its vulnerability to corruption, its tendency to detract from academics, among other problems. If I am only glad in the qualified sense that Indiana won, given the existence of the NCAA, then I am only circumstantially glad of that fact. By contrast, suppose I am glad Indiana won the championship regardless. That is to say, I prefer this state of affairs to no tournament at all, despite whatever drawbacks the NCAA represents. In this case, we can say that I am glad on the whole for Indiana's championship.

The question Hasker wants to pose to his readers is the far more personal one of whether they are glad that they and their loved ones are alive. This is a "person-relative" question in the sense that each person must answer it for himself. While some may return 
a negative answer because of the harsh reality of severe suffering, Hasker believes most would readily agree that they are glad that they and their loved ones are alive.

Now this question is a philosophically interesting one for several reasons. Hasker's main concern however, is with issues which arise from the fact that for many, if not most of us, our very existence is inextricably connected with tragic events in the past. Hasker illustrates this by sharing the contingencies involved in his own birth. His parents came from widely separated parts of the country and they happened to meet through a series of large scale events that involved several other people as well. The most significant of these events was nothing less than World War I, which sent his father to France and led his mother to move to our nation's capital to work for the government. In short, Hasker has excellent reason to believe that had there been no war, he would never have been born. Moreover, there are no doubt similar complexities that brought together many of his progenitors of earlier generations. In view of all these considerations, Hasker formulates the following general principle.

Had major or significant events in the world's past history been different than they were, then in all probability neither I nor the persons whom I love would ever have existed (Hasker 1981, p. 156).

Here it is important to notice that Hasker's argument hinges on a particular thesis about personal identity, namely, that each of us is initially individuated by his body. That is to say, if the particular body of Hasker's had not been conceived and born, then Hasker would never have existed. On this view, each soul is correlated to a particular body in a manner like that suggested by Aquinas who held that the soul is the form of the body. That is to say, each particular soul is individuated by the particular body which it informs. Consequently, if the man who is Hasker's father had married a different woman, or even have impregnated his wife at a different time, then Hasker would not be here formulating arguments along this line.

Now it is quite interesting to see what follows from Hasker's view of personal identity, along with his definition of what it means to be glad on the whole. In the first place, consider the significant implication of what it means to be glad on the whole that something is the case.

If I am glad on the whole that $P$, and I know that if $Q$ did not obtain neither would P, than I rationally must be glad that Q (Hasker 1981, p. 159).

When we combine this implication with his thesis about personal identity, we get this striking result:

If I am glad on the whole about my own existence and that of those whom I love, then I must be glad that the history of the world, in its major aspects, has been as it is (Hasker 1981, p. 159).

Here it is important to see that this consequence is not only striking, but also disconcerting. In view of it, we may even be tempted to reconsider our previous claim about being glad of our existence. Hasker finds this reaction understandable. "Perhaps, indeed, your reaction is one of bewilderment-you may feel, as a colleague suggested, that when you lump your life together with whole past history of the world, you don't know what to say about it." (Hasker 1981, p. 162). In this case, one may simply have no "on the whole" attitude about his existence and find himself entirely perplexed. As Hasker contends, the person who is merely bewildered is not properly situated to press the problem of evil as an objection against the existence of God. In order to make that argument effectively, one must positively regret his existence as well as that of those he loves.

My primary aim here is neither to defend nor to criticize Hasker's central argument although I am inclined to think it is sound. What I do want to highlight, however, is that the doctrine of heaven is a powerful resource to relieve the perplexity engendered by Hasker's argument. So let us proceed by first spelling out a bit more fully the nature of this perplexity. This perplexity is due, I think, to a sense that we have no moral right to be glad 
for our existence if our existence is contingent in some way on events which have brought terrible suffering and misery to other persons. Indeed, to be glad in such circumstances may seem obliviously self-centered or even clueless. It is hard to say exactly why, but it is almost as if those who have suffered before us, and with whom our own existence is inextricably and undeniably connected, have a moral claim against us and our happiness. To be rightly happy, it seems almost as if we somehow need their blessing or approval, perhaps even their forgiveness.

Since we cannot have this, we may feel that we owe it to them to regret our own existence. However, this is at best a rather vague and perhaps undefined feeling. Exactly what would be involved in regretting one's own existence in this sense? Would we be required actually to prefer that we, as well as those we love, did not in fact exist? And, if we were truly sincere and not merely engaging in empty hand wringing and guilt mongering, should such a preference lead us to suicide or even murder? Or should it merely involve a determined choice not to be happy, a choice to bear the suffering of others in our heart in such a way that we never experiences any real joy or take any deep satisfaction in life?

In any case, there is one thing it cannot mean and that is wishing we had never been born or wishing that past tragedies had not occurred. The reason is simple. What we can wish for must at the very least be possible, but it is not coherent to wish, strictly speaking, that the past were different than it is. ${ }^{2}$ We can regret the past, but once a thing has happened, we cannot wish it away as never having happened. Our only real hope is that the past might somehow be redeemed. And, this is precisely the key to relieving the bewilderment Hasker identifies. More specifically, the doctrine of heaven represents our best hope that the past might be redeemed in such a way that we can be fully glad for our lives even if our existence is somehow implicated in some of the worst tragedies of human history. Heaven holds out the promise that persons who have suffered in terrible ways and died premature deaths have not been consigned to oblivion. The countless persons who have died in wars are not merely the waste product of human history who had to be sacrificed so that later generations could enjoy lives for which they are truly grateful.

Elsewhere, I have defended the notion of optimal grace, the notion that God will do everything He can, short of overriding freedom, to save all persons (Walls 2002, pp. 83-88). Indeed, God will compensate for lack of opportunity to receive salvation in this life and make sure that all persons have not only a fair, but a full opportunity to freely receive the eternal life for which all persons were created. And, if this is so, then all persons, without exception, will have the opportunity to experience full satisfaction and happiness. The only ones who are not finally saved will be those who simply will not accept what God freely offers, who persistently and decisively refuse his offer of grace.

Indeed, this is the final issue for all persons who have ever lived, whatever their fate may be in this life. The only hope for true happiness and full satisfaction for those who have suffered greatly and tragically is precisely the same as that of persons whose temporal lives in this world have been marked by joy and pleasure.

In view of all of this, I do not think anyone has reason to refuse the joy of life, or worse, regret his very existence. This is not to deny that in this life there are many occasions to grieve and mourn, but the mourning of the believer in heaven is set in the larger context of hope for a day of redemption that will dry all tears and heal all hurts. This is the essential hope that relieves the perplexity and bewilderment of being glad of our existence even while recognizing that our existence is contingent on tragedies which would otherwise be unspeakable.

\section{Conclusions}

In her book, Evil in Modern Thought, Susan Neiman tells the story of how modernity attempted to resolve the problem of evil. The Lisbon earthquake, shocking to a world that believed in a good God, was eventually thought not be an evil, but merely an unfortunate natural event. Moral evil, by contrast, was harder to domesticate and think about rationally. Neiman recognizes that even in our contemporary world, theodicy is tempting for those 
who want to make sense of evil and to feel like there is reason to go on with the challenges of life. While Neiman feels the temptation of theodicy, she resists the hope that truth, beauty and goodness will ever converge in our world. The conflict between our hopes and reality is one that will never be resolved, and we must be satisfied with more modest expectations. As an example of what we may realistically hope for, she pointed to the courageous passengers on Flight 93 who resisted the terrorists on 9/11. "They proved not only that human beings have freedom; we can use it to affect a world we fear we don't control. This is not theodicy. It is not even consolation-though it is all the hope we have." (Neiman 2002, p. 288).

Given the rational constraints on hope imposed by her atheism, Neiman's stance is altogether understandable. I have argued in this essay, however, that there is reason to hope for much more, even for those who face the horrors of this world with wide eyed clarity and honesty.

Funding: This research received no external funding.

Data Availability Statement: Not applicable.

Conflicts of Interest: The author declares no conflict of interest.

\section{Notes}

1 I have defended a Protestant account of purgatory in (Walls 2012).

2 Certainly it is logically possible that the past was different. There are possible worlds in which the past is different and in which our existence comes about with less suffering. However, alas, in the actual world, it remains incoherent to wish the past was different. We are stuck with the actual world, including its actual past.

\section{References}

Adams, Marilyn McCord. 1992. Redemptive Suffering: A Christian Solution to the Problem of Evil. In The Problem of Evil: Selected Readings. Edited by Michael L. Peterson. Notre Dame: The University of Notre Dame Press, p. 183.

Adams, Marilyn McCord. 1999. Horrendous Evils and the Goodness of God. Ithaca: Cornell University Press, p. 148.

Creel, Richard. 1986. Divine Impassibility: An Essay in Philosophical Theology. Cambridge: Cambridge University Press, p. 149.

Dostoyevsky, Fyodor. 1992. The Brothers Karamazov. Translated by Constance Garnett. New York: Modern Library, p. 254.

Hasker, William. 1981. On Regretting the Evils of This World. In The Problem of Evil: Selected Readings. Oxford: Oxford University Press. Lewis, C. S. 2001. Mere Christianity. San Francisco: Harper, p. 199.

Neiman, Susan. 2002. Evil in Modern Thought: An Alternative History of Philosophy. Princeton: Princeton University Press, p. 288.

van Inwagen, Peter. 1994. Quam Dilecta. In God and the Philosophers. Edited by Thomas V. Morris. New York: Oxford University Press, p. 97.

Walls, Jerry L. 2002. Heaven: The Logic of Eternal Joy. New York: Oxford University Press.

Walls, Jerry L. 2012. Purgatory: The Logic of Total Transformation. New York: Oxford University Press. 